\title{
The acid-tolerant L-arabinose isomerase from the mesophilic Shewanella sp. ANA-3 is highly active at low temperatures
}

Moez Rhimi ${ }^{*}$, Goran Bajic ${ }^{1}$, Rimeh Ilhammami ${ }^{1}$, Samira Boudebbouze ${ }^{2}$, Emmanuelle Maguin², Richard Haser ${ }^{1}$ and Nushin Aghajari ${ }^{1^{*}}$

\begin{abstract}
Background: L-arabinose isomerases catalyse the isomerization of L-arabinose into L-ribulose at insight biological systems. At industrial scale of this enzyme is used for the bioconversion of D-galactose into D-tagatose which has many applications in pharmaceutical and agro-food industries. The isomerization reaction is thermodynamically equilibrated, and therefore the bioconversion rates is shifted towards tagatose when the temperature is increased. Moreover, to prevent secondary reactions it will be of interest to operate at low pH. The profitability of this D-tagatose production process is mainly related to the use of lactose as cheaper raw material. In many dairy products it will be interesting to produce D-tagatose during storage. This requires an efficient L-arabinose isomerase acting at low temperature and $\mathrm{pH}$ values.

Results: The gene encoding the L-arabinose isomerase from Shewanella sp. ANA-3 was cloned and overexpressed in Escherichia coli. The purified protein has a tetrameric arrangement composed by four identical $55 \mathrm{kDa}$ subunits. The biochemical characterization of this enzyme showed that it was distinguishable by its maximal activity at low temperatures comprised between $15-35^{\circ} \mathrm{C}$. Interestingly, this biocatalyst preserves more than $85 \%$ of its activity in a broad range of temperatures from 4.0 to $45^{\circ} \mathrm{C}$. Shewanella sp. ANA-3 L-arabinose isomerase was also optimally active at pH 5.5-6.5 and maintained over $80 \%$ of its activity at large pH values from 4.0 to 8.5. Furthermore, this enzyme exhibited a weak requirement for metallic ions for its activity evaluated at $0.6 \mathrm{mM} \mathrm{Mn}^{2+}$. Stability studies showed that this protein is highly stable mainly at low temperature and $\mathrm{pH}$ values. Remarkably, T268K mutation clearly enhances the enzyme stability at low pH values. Use of this L-arabinose isomerase for D-tagatose production allows the achievement of attractive bioconversion rates of 16\% at $4^{\circ} \mathrm{C}$ and $34 \%$ at $35^{\circ} \mathrm{C}$.

Conclusions: Here we reported the purification and the biochemical characterization of the novel Shewanella sp. ANA-3 L-arabinose isomerase. Determination of the biochemical properties demonstrated that this enzyme was highly active at low temperatures. The generated T268K mutant displays an increase of the enzyme stability essentially at low $\mathrm{pH}$. These features seem to be very attractive for the bioconversion of D-galactose into Dtagatose at low temperature which is very interesting from industrial point of view.
\end{abstract}

Keywords: L-arabinose isomerase, acid-tolerant, cold-active, D-tagatose

\footnotetext{
* Correspondence: rhimimoez@yahoo.fr; n.aghajari@ibcp.fr

'Laboratory for BioCrystallography and Structural Biology of Therapeutic

Targets, "Bases Moléculaires et Structurales des Systèmes Infectieux" UMR5086 CNRS/Université de Lyon1, Institut de Biologie et Chimie des Protéines FR3302, 7 Passage du Vercors, F-69367 Lyon cedex 07, France Full list of author information is available at the end of the article
} 


\section{Background}

L-Arabinose isomerase, hereafter L-AI, (EC 5.3.1.4) converts $\mathrm{L}$-arabinose into $\mathrm{L}$-ribulose within living systems [1]. This enzyme is also known as D-galactose isomerase due to its capacity to isomerize D-galactose into D-tagatose in vitro [2,3]. Over the past years, rare sugars have made their way to the market and the demands have been increased as in agro-food industry rare natural sugars such as D-tagatose have become of a great interest as sweeteners [4]. Indeed this natural sugar has the taste and natural properties of sucrose but it is an antihyperglycemiant factor known to reduce symptoms associated with type 2 diabetes [5,6]. D-Tagatose has not only a very low caloric value of $1.5 \mathrm{kcal} / \mathrm{g}$ (only $30 \%$ of the energy content of sucrose), but has also been reported to promote weight loss [5]. All these properties are very interesting for industrials, yet the use of this sugar is quite limited due to its cost [7]. In fact, chemical methods used at present to produce D-tagatose are very expensive. Therefore, biological methods using Larabinose isomerase as a catalyst are being developed due to its low cost [8].

Many micro-organisms such as Arthrobacter, Lactobacillus, Mycobacterium, Klebsiella and Gluconobacter are able to convert D-galactitol into D-tagatose [9]. However, this production procedure is not attractive due to the high cost of the raw material D-galactitol. That is why studies are now investigating a new bioprocess, which consists in converting D-galactose into D-tagatose using L-AIs. These studies have shown that the reaction equilibrium shifts towards D-tagatose production with increased temperatures, and that the majority of L-AIs are thermoactive biocatalysts requiring metal ions for their maximal thermostability and activity [3,10-14]. Unfortunately, for industrial purposes high temperatures and alkaline $\mathrm{pH}$ result in the formation of side reactions generating undesirable by-products that should be removed (together with the metal ions) at the end of the process, thus increasing the production costs $[7,15]$. For these reasons, highly thermoactive L-AIs deriving from thermophilic strains such as Bacillus stearothermophilus US100, Thermotoga maritima, Thermotoga neapolitana, Geobacillus thermodenitrificans and Thermus sp. were identified [12,13,16-18]. Many industrial applications including bioconversion of $\mathrm{D}$-galactose to $\mathrm{D}$-tagatose during products storage, which must be done at low temperatures, require an L-AI that acts not only at acidic $\mathrm{pH}$ but also at low temperatures. To satisfy these requirements, screening of novel L-AIs has been done. As a result, many L-AIs were identified and characterized to be functional at relatively high $\mathrm{pH}$ and at high temperatures [10-18]. Lately, four L-AIs from Alicyclobacillus acidocaldarius, Bacillus licheniformis, Lactobacillus plantarum NC8 and Lactobacillus sakei $23 \mathrm{~K}$ strains were described to be acid-tolerant. Molecular determinants for the catalytic efficiency were explored by homology modeling followed by site-directed mutagenesis $[19,20]$. Protein engineering was also used to generate enzymes acting at low temperatures, such as the N175H mutant from B. stearothermophilus US100 [15,20-22] and at acidic pH (mutant Q268K) [22]. On the basis of these two mutants a third one was developed (Q268K/ N175K) [22]. This double mutant is highly active at both acidic $\mathrm{pH}$ and low temperatures making it very promising for industrial D-tagatose production. Nevertheless, it remains of interest to set out a stable L-AI active at even lower temperatures.

Here we report the cloning, over-expression, purification and biochemical characterization of an L-AI isolated from Shewanella sp. ANA-3. The activity and stability of the enzyme at low temperatures is discussed in comparison with previously described L-AIs. Site-directed mutagenesis has been performed to generate the T268K mutant and explore its biochemical properties.

\section{Results and discussion}

\section{Gene, cloning and over-expression}

A DNA fragment of approximately $1.5 \mathrm{~kb}$ was obtained by polymerase chain reaction (PCR) amplification using Shewanella sp. ANA-3 chromosomal DNA as template and the two oligonucleotides. DNA was ligated into the pGEMT-Easy vector and then transferred into the Escherichia coli BL21 (DE3) host strain. Numerous white colonies were observed and subsequently analyzed with the appropriate restriction endonucleases; a recombinant clone carrying the $\operatorname{araA}$ gene under the control of T7 promoter was obtained (pMR37). Then, the araA gene was sub-cloned in pET-15b under control of the T7 promoter leading to the pMR38 plasmid. Monitoring of liquid culture (BL21/pMR38 strain), followed by an LAI activity test in the crude extract, showed an activity of $26 \mathrm{U} / \mathrm{mg}$, confirming the molecular cloning and the expression of Shewanella sp. ANA-3 araA under the control of the T7 promoter. This latter gene encodes a 500 amino-acid residues protein with a calculated molecular mass of $55.3 \mathrm{kDa}$. Inspection of the amino-acid sequence multiple alignment of this protein with several other L-AIs indicated that Shewanella sp. ANA-3 L-AI displays the highest sequence identity (54.5\%) with L-AI from the acidophilic strain $A$. acidocaldarius. Other enzymes such as those from B. licheniformis, L. plantarum NC8 and L. sakei $23 \mathrm{~K}$, share 50.5\%, 40.7\% and $38.7 \%$ sequence identity, with Shewanella sp. ANA-3 LAI, respectively (Figure 1). Sequence alignments with the thermophilic G. stearothermophilus, B. stearothermophilus US100, B. thermodenitrificans, T. neapolitana and 
T. maritima showed significative identity of $54.2 \%$, $54.4 \%, 54.3 \%, 47.7 \%$ and $48.3 \%$, respectively (Figure 1 ).

\section{Purification of the Shewanella sp. ANA-3 L-AI}

After an over-night liquid cell culture of the BL21/ pMR38 strain, the protein crude extract was subjected to fractioned precipitation with ammonium sulfate (Figure $2 \mathrm{~A}$ ). The subsequent step consisted in loading the resolubilized fractions onto a HiTrap ${ }^{\mathrm{TM}}$ Chelating Immobilized Metal Affinity Chromatography (IMAC) column. A high purity enzyme extract was achieved with size exclusion chromatography (Figure 2A). The single elution peak obtained has an apparent molecular mass of $230 \mathrm{kDa}$ (Figure 2B). Electrophoresis under reducing conditions (12\% SDS-PAGE; sodium dodecyl sulfatepolyacrylamide gel electrophoresis) revealed a homogenous band with a molecular mass of about $55 \mathrm{kDa}$ (Figure 2A), suggesting that Shewanella sp. ANA-3 L-AI is a tetramer composed by four monomers of $55-\mathrm{kDa}$. Previous studies showed that all L-AIs have a similar, homotetrameric quaternary structure $[11,13-15,18]$ the exception being $E$. coli $\mathrm{L}$-AI which forms a homohexamer [23]. Presently, the only known L-AI 3D-structure is that of E. coli [23], and further structural studies would be of high interest in order to explore the importance of the quaternary structures in D-galactose binding and/or catalysis. Shewanella sp. ANA-3L-AI presented a relatively high specific activity of $164 \mathrm{U} / \mathrm{mg}$ making it more active than most L-AIs from mesophilic bacterial origin (Table 1). Only few of the currently characterized L-AIs exhibit higher specific activity, mainly those from thermophilic bacteria like B. stearothermophilus US100 (185 $\mathrm{U} / \mathrm{mg}$ ) and T. neapolitana (119 U/mg) or lactic acid bacteria as $L$. sakei $(218 \mathrm{U} / \mathrm{mg})[10,13,24]$.

\section{Effects of temperature, $\mathrm{pH}$ and metallic ions on L-Al activity}

Shewanella sp. ANA-3 L-AI was optimally active within a large range of temperatures from 15 to $35^{\circ} \mathrm{C}$, and highly active at low temperatures preserving nearly $90 \%$ to $95 \%$ of its optimal activity at 4 to $10^{\circ} \mathrm{C}$, respectively. At 40 to $45^{\circ} \mathrm{C}$, the protein retained $90 \%$ to $85 \%$ of its

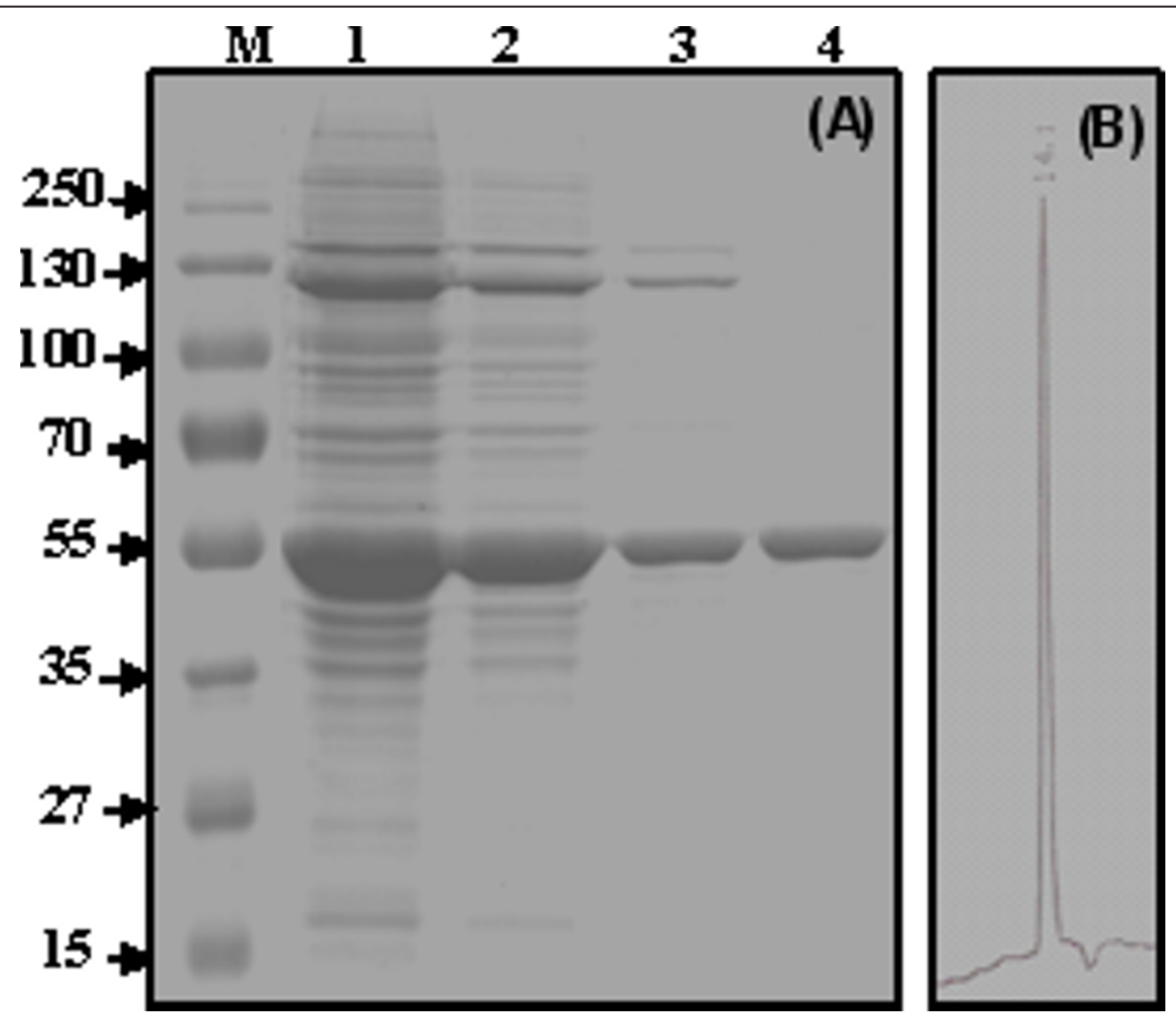

Figure 2 Electrophoretic and size exclusion FPLC analysis of the purified Shewanella enzyme. (A) SDS-PAGE showing the various steps in the purification procedure under reducing conditions. Lane M, protein markers (molecular masses in $\mathrm{kDa}$ ); lane 1, total cell extract; lane 2, sample from lane 1 after ammonium sulphate precipitation; lane 3, sample from lane 2 after affinity chromatography; lane 4, purified recombinant L-Al after size exclusion chromatography. (B) Size exclusion HPLC analysis of the purified recombinant Shewanella sp. ANA-3 L-Al shows a single peak of $230 \mathrm{kDa}(\mathrm{RT}=14.1 \mathrm{~min})$, using protein markers of $669 \mathrm{kDa}$ ( $R T=8.755 \mathrm{~min}), 440$ (RT = $13.165 \mathrm{~min}), 232$ (RT = $14.02 \mathrm{~min}$; $R T$, retention time), $140(R T=17.163 \mathrm{~min})$ and $66(R T=21.438 \mathrm{~min})$. 
Table 1 Biochemical properties of previously reported L-Als

\begin{tabular}{|c|c|c|c|c|c|c|}
\hline Organism & Topt $\left({ }^{\circ} \mathrm{C}\right)$ & $\mathrm{pH}$ & $\begin{array}{l}\text { Metal ion } \\
\text { Requirement (mM) }\end{array}$ & $K \mathrm{~m}(\mathrm{mM})$ & Vmax (mmole/s/mg) & References \\
\hline Shewanella sp. ANA-3 & $15-35$ & $5.5-6.5$ & $\mathrm{Mn}^{2+}(0.6)$ & $33.7^{*}$ & $164^{*}$ & This study \\
\hline Acidothermus cellulolytics & 75 & 7.5 & $\mathrm{Mn}^{2+}(1.0), \mathrm{Co}^{2+}(0.5)$ & NR & NR & {$[35]$} \\
\hline Alicyclobacter acidocaldarius & 50 & 6.0 & $\mathrm{Mn}^{2+}(1.0), \mathrm{Co}^{2+},(1.0) \mathrm{Mg}^{2+}(1.0)$ & 48 & 35.5 & {$[15]$} \\
\hline Anoxybacillus flavithermus & 95 & $9.5-10.5$ & $\mathrm{Ni}^{2+}(1.0)$ & 78.5 & 94.3 & {$[25]$} \\
\hline Bacillus stearothermophilus US100 & 80 & $7.5-8.0$ & $\mathrm{Mn}^{2+}(1.0), \mathrm{Co}^{2+}(0.2)$ & 28.57 & 185 & [13] \\
\hline Bacillus halodurans & 50 & $7.5-8.0$ & $\mathrm{Mn}^{2+}(1.0)$ & 36 & 33.1 & {$[27]$} \\
\hline Bacillus licheniformis & 50 & 7.5 & $\mathrm{Mn}^{2+}(1.0), \mathrm{Co}^{2+}(1.0)$ & 369 & NR & [14] \\
\hline Bacillus subtilis & 32 & 7.5 & $\mathrm{Mn}^{2+}(1.0)$ & 120 & NR & {$[36]$} \\
\hline Escherichia coli & 30 & 8.0 & $\mathrm{Mn}^{2+}(0.5)$ & 60 & NR & {$[37]$} \\
\hline Geobacillus stearothermophilus T6 & 70 & $7.0-7.5$ & $\mathrm{Mn}^{2+}(1.0)$ & 63 & 36.5 & {$[1]$} \\
\hline Geobacillus thermodenitrificans & 60 & 7.5 & $\mathrm{Mn}^{2+}(5.0), \mathrm{Co}^{2+}(3.0)$ & 142 & 86 & {$[12]$} \\
\hline Lactobacillus fermentum & 65 & 6.5 & $\mathrm{Mn}^{2+}(1.0), \mathrm{Co}^{2+}(2.0)$ & 29.9 & 24.3 & {$[38]$} \\
\hline Lactobacillus plantarum NC8 & 60 & 7.5 & $\mathrm{Mn}^{2+}(1.0), \mathrm{Co}^{2+}(0.5)$ & 43.42 & 40 & {$[21]$} \\
\hline Lactobacillus sakei $23 \mathrm{~K}$ & $30-40$ & $5.0-7.0$ & $\mathrm{Mg}^{2+}(0.8), \mathrm{Mn}^{2+}(0.8)$ & 31.6 & 264 & [24] \\
\hline Thermotoga maritima & 90 & 7.0 & $\mathrm{Mn}^{2+}(5.0), \mathrm{Co}^{2+}(1.0)$ & 63 & 41.3 & {$[26]$} \\
\hline Thermotoga neapolitana & 85 & $7.0-7.5$ & $\mathrm{Mn}^{2+}(1.0), \mathrm{Co}^{2+}(1.0)$ & 60 & 119 & {$[10]$} \\
\hline Thermus sp. IM6501 & 60 & 8.5 & $\mathrm{Mn}^{2+}(5.0)$ & NR & NR & {$[18]$} \\
\hline Bacillus stearothermophilus IAM1101 & 65 & 6.0 & $\mathrm{MnP}^{2+\mathrm{P}}(1.0)$ & NR & NR & [39] \\
\hline
\end{tabular}

NR: Not Reported

Top: Optimal temperature

*: Substrate is L-arabinose

activity, respectively, whereas at higher temperatures (> $45^{\circ} \mathrm{C}$ ) the relative activity rapidly decreased. This pronounced activity at low temperatures distinguishes it from all previously described L-AIs (Table 1), and another interesting feature is that more than $85 \%$ of its maximal activity is maintained in a wide range of temperatures from 4 to $45^{\circ} \mathrm{C}$. This behavior indeed promotes the use of this enzyme in agro-food industry. Study of the effect of $\mathrm{pH}$ on this L-AI demonstrates that this protein was highly active at $\mathrm{pH}$ 5.5-6.5. Furthermore, the enzyme retains more than $80 \%$ of its activity from $\mathrm{pH} 4.0$ to 8.5 . Remarkably, this protein preserves more than $60 \%$ of its relative activity at $\mathrm{pH} 3.0$ and 3.5, whereas the majority of the earlier reported L-AIs have optimal pH values of 7.0-8.0 (Table 1). For instance, all L-AIs from Bacillus genera possess a rather narrow range of optimal $\mathrm{pH}$ from 7.0 to 8.5. Concerning L-AIs from lactic acid bacteria, the optimum $\mathrm{pH}$ values are more acidic spanning from 5.0 to 7.5 , and the most acid tolerant candidate being L. sakei $23 \mathrm{~K}$ L-AI functioned at $\mathrm{pH}$ 5.0-7.0 [24]. In contrast, some L-AIs act at highly alkaline conditions; such is the case of Anoxybacillus flavithermus $\mathrm{L}-\mathrm{AI}$ that has an optimal $\mathrm{pH}$ range from 9.5 to 10.5 [25]. However, the acid tolerance is important mainly for industrial purposes. In fact, isomerization of D-galactose under acid $\mathrm{pH}$ prevents the formation of unwanted products [26,27].

Treatment of the enzyme with ethylenediaminetetraacetic acid (EDTA) showed a 74\% decrease in the activity.
Amongst several metal ions only $\mathrm{Mn}^{2+}$ restored the enzyme activity, which exceeded that observed for the metal-depleted enzyme by 1.6 fold (Figure 3A), at a concentration of only $0.6 \mathrm{mM} \mathrm{Mn}^{2+}$ (Figure 3B). Analysis of the EDTA-treated enzyme by flame atomic absorption spectrometry demonstrates the presence of only manganese; thus highlighting its tight interaction with protein. This explains the residual activity (26\%) obtained after enzyme EDTA treatment. Comparatively to all reported L-AIs, the present enzyme showed a weak requirement for metal ions for its optimal activity (Table 1). This feature is highly advantageous for its potential use in agrofood industry where many metal ions are not authorized, and therefore if used should be discarded from the final products, thereby increasing the process costs [7].

\section{Shewanella sp. ANA-3 thermal and pH stability studies}

Enzyme stability is a crucial criterion for industrial applications. Our study showed that without addition of metal ions this enzyme was fully stable at temperatures below $35^{\circ} \mathrm{C}$. At $40^{\circ} \mathrm{C}$ the enzyme upheld more than $80 \%$ of its activity after two hours, and at 45 and $50^{\circ} \mathrm{C}$ the enzyme stability decreased with half-lives of 90 and 40 min, respectively (Figure 4A).

After addition of $0.6 \mathrm{mM} \mathrm{Mn}^{2+}$ the enzyme was completely stable for 1 hour at $40^{\circ} \mathrm{C}$ and preserved $90 \%$ of its activity after two hours of incubation. Addition of manganese clearly improved the thermal stability at 45 and $50^{\circ} \mathrm{C}$, the enzyme retained more than $50 \%$ of its 

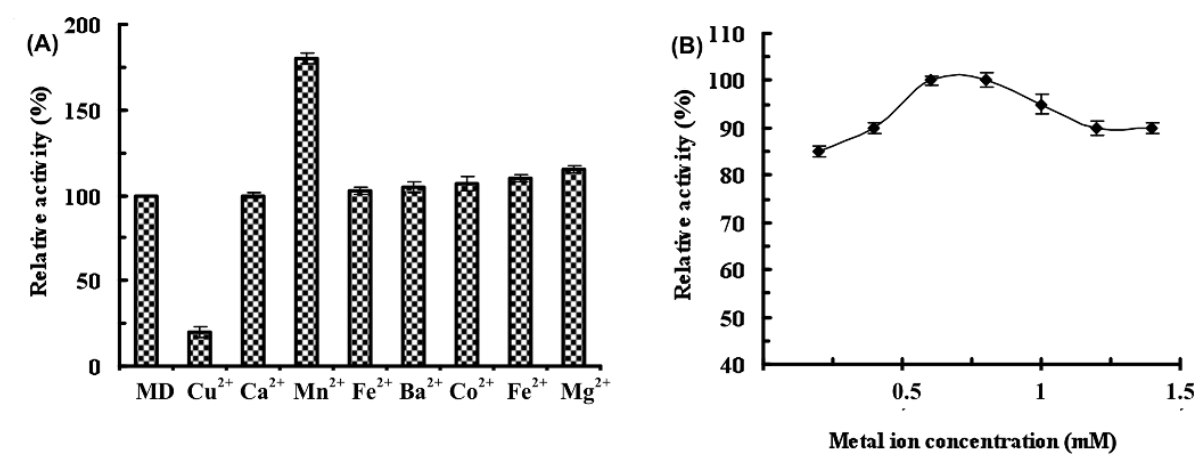

Figure 3 Shewanella sp. ANA-3 L-Al activity. (A): Effect of divalent metal ions. (B): Effect of various concentrations of $\mathrm{Mn}^{2+}(\boldsymbol{})$. "MD" indicates enzyme activity measured in a metal depleted solution. Activities at optimal metal ion concentrations were defined as $100 \%$. Error bars represent the standard deviation from three independent experiments.

initial activity after two hours (Figure 4B). These results give evidence that $\mathrm{Mn}^{2+}$ ions play a crucial role in the stabilization of the enzyme at high temperatures. This phenomenon is well reported for L-AIs, requiring metal ions for their stability (Table 1). Study of the enzyme stability at different $\mathrm{pH}$ values demonstrates that this biocatalyst has high half-lives in a wide $\mathrm{pH}$ range from 4.5 to 7.0 (Table 2). Furthermore, at $\mathrm{pH} 3.0$ to 4.0 and 7.5 to 8.5 the half-lives dropped slightly. Variations of temperature from 4 to $30^{\circ} \mathrm{C}$ were not significant, but highlighting the stability of the Shewanella enzyme in a large range of temperatures and $\mathrm{pH}$.

Using sequence alignment, Lee et al. (2005) identified Lys269 in Alicyclobacillus acidocaldarius L-AI as an important determinant for enzyme's acid tolerance [15]. This hypothesis was confirmed by generating mutants that shifted the optimum $\mathrm{pH}$ by one unit towards more alkaline $\mathrm{pH}$ [15]. Guided by these studies, we have explored the influence of the non conserved lysine residue at position 268 on the biochemical properties of the Shewanella sp. ANA-3 enzyme (Figure 1). By site- directed mutagenesis we replaced the corresponding threonine by a lysine, and our data indicate that this mutation does not affect the enzymatic activity at different temperatures. As for the relative activity profile at different $\mathrm{pH}$ values, it seems that the T268K mutation increases the enzyme activity mostly at highly acidic $\mathrm{pH}$. Remarkably, the wild-type Shewanella L-AI upholds more than $60 \%$ of its activity at $\mathrm{pH} 3.0$ and the T268K mutant is even more acid-tolerant, retaining $80 \%$ of its activity at the same $\mathrm{pH}$. Also, analysis of this mutant stability at different $\mathrm{pH}$ and different temperatures demonstrates that the T268 K L-AI mutant displays higher half-lives with low $\mathrm{pH}$ (3.0-4.5) when compared to the wild-type enzyme (Table 2). Similar half-lives were obtained for both mutant and wild-type Shewanella sp. ANA-3 L-AIs at pH's from 5.0 to 7.0. Remarkably, T268K L-AI mutant displays a maximal stability at low $\mathrm{pH}$ value of 5.5 and high value of 7.0. Thus, this mutant is not only more acid-tolerant than the wildtype enzyme, but also more stable under acidic $\mathrm{pH}$ and low temperatures. This takes more importance when we
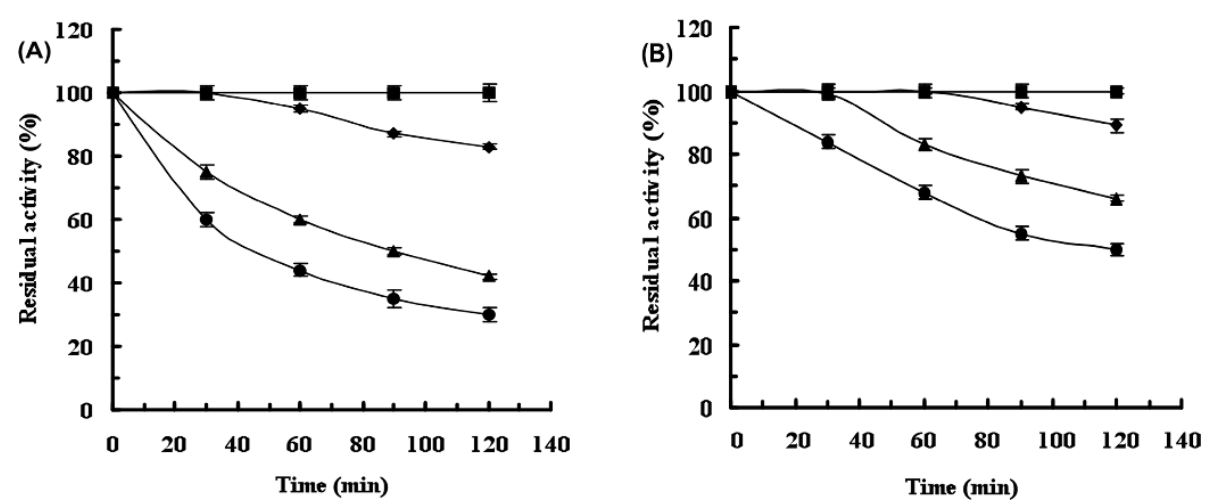

Figure 4 Thermostability profiles of (A) the metal depleted wild-type Shewanella sp. ANA-3 L-Al and (B) in the presence of $0.6 \mathrm{mM}$ $\mathrm{Mn}^{2+}:(\bullet) 35^{\circ} \mathrm{C},(\bullet) 40^{\circ} \mathrm{C},(\bullet) 45^{\circ} \mathrm{C}$ and $(\bullet) 50^{\circ} \mathrm{C}$. The initial activity was defined as $100 \%$. Error bars represent the standard deviation from three independent experiments. 
Table $2 \mathrm{pH}-$ Stability of wild-type L-AI and its T268K mutant (values within brackets) at different temperatures without addition of metal ions

\begin{tabular}{|c|c|c|c|c|}
\hline \multirow[b]{2}{*}{$\mathrm{pH}$} & \multirow[b]{2}{*}{4} & \multirow[b]{2}{*}{10} & \multicolumn{2}{|l|}{ Temperature $\left({ }^{\circ} \mathrm{C}\right)$} \\
\hline & & & 20 & 30 \\
\hline & & & Half-lives $\left(t_{1 / 2}, h\right)$ & \\
\hline 3.0 & $27 \pm 0.2(39 \pm 0.1)$ & $28 \pm 0.1(38 \pm 0.3)$ & $27 \pm 0.4(38 \pm 0.7)$ & $27 \pm 0.1(38 \pm 0.4)$ \\
\hline 3.5 & $32 \pm 0.3(39 \pm 0.7)$ & $33 \pm 0.5(39 \pm 0.2)$ & $32 \pm 0.1(39 \pm 0.1)$ & $31 \pm 0.2(40 \pm 0.5)$ \\
\hline 4.0 & $35 \pm 0.4(40 \pm 0.3)$ & $34 \pm 0.4(41 \pm 0.7)$ & $35 \pm 0.4(41 \pm 0.4)$ & $36 \pm 0.3(41 \pm 0.8)$ \\
\hline 4.5 & $39 \pm 0.6(42 \pm 0.5)$ & $39 \pm 0.4(43 \pm 0.4)$ & $38 \pm 0.8(43 \pm 0.2)$ & $39 \pm 0.6(42 \pm 0.3)$ \\
\hline 5.0 & $41 \pm 0.2(42 \pm 0.4)$ & $42 \pm 0.3(43 \pm 0.2)$ & $40 \pm 0.5(44 \pm 0.8)$ & $41 \pm 0.8(42 \pm 0.9)$ \\
\hline 5.5 & $43 \pm 0.7(43 \pm 0.8)$ & $44 \pm 0.2(44 \pm 0.6)$ & $44 \pm 0.6(44 \pm 0.2)$ & $43 \pm 0.4(43 \pm 0.2)$ \\
\hline 6.0 & $43 \pm 0.5(43 \pm 0.2)$ & $44 \pm 0.6(44 \pm 0.8)$ & $44 \pm 0.7(44 \pm 0.5)$ & $43 \pm 0.7(43 \pm 0.4)$ \\
\hline 6.5 & $43 \pm 0.2(44 \pm 0.6)$ & $44 \pm 0.1(44 \pm 0.5)$ & $44 \pm 0.5(44 \pm 0.6)$ & $43 \pm 0.4(44 \pm 0.5)$ \\
\hline 7.0 & $44 \pm 0.8(44 \pm 0.4)$ & $44 \pm 0.8(44 \pm 0.2)$ & $44 \pm 0.2(44 \pm 0.3)$ & $43 \pm 0.1(44 \pm 0.1)$ \\
\hline 7.5 & $43 \pm 0.2(43 \pm 0.6)$ & $43 \pm 0.3(43 \pm 0.4)$ & $43 \pm 0.1(43 \pm 0.3)$ & $43 \pm 0.5(43 \pm 0.4)$ \\
\hline 8.0 & $41 \pm 0.5(41 \pm 0.6)$ & $41 \pm 0.6(42 \pm 0.3)$ & $42 \pm 0.2(42 \pm 0.1)$ & $42 \pm 0.7(42 \pm 0.6)$ \\
\hline 8.5 & $40 \pm 0.6(40 \pm 0.5)$ & $40 \pm 0.7(40 \pm 0.8)$ & $40 \pm 0.5(40 \pm 0.7)$ & $40 \pm 0.7(40 \pm 0.9)$ \\
\hline
\end{tabular}

consider that an attractive enzyme, from industrial point of view, should be stable and efficient. Such data confirm the essential role of the K268 residue on both acidtolerance and $\mathrm{pH}$ stability of L-AIs.

\section{Kinetic characterization and D-galactose bioconversion}

Determination of the kinetic parameters of the Shewanella sp. ANA-3 L-AI showed that it has $K_{\mathrm{m}}$ values of 33.7 and $52.1 \mathrm{mM}$ for L-arabinose and D-galactose, respectively. Furthermore the $V_{\max }$ was $164 \mathrm{mmole} / \mathrm{s} /$ $\mathrm{mg}$ for L-arabinose and $44 \mathrm{mmole} / \mathrm{s} / \mathrm{mg}$ for D-galactose. To further explore the efficiency of this enzyme to produce D-tagatose, we carried out D-galactose bioconversion at different temperatures. As shown in Table 3 the highest bioconversion rate (34\%) was obtained at $35^{\circ} \mathrm{C}$. At lower temperatures including 30, 20, 10 and $4^{\circ} \mathrm{C}$ maximum bioconversion levels of $31 \%, 25 \%, 21 \%$ and $16 \%$ were obtained, respectively. These data underline the catalytic efficiency of this enzyme to produce D-tagatose at low temperature. In addition, analysis of Table 3 demonstrates that bioconversion rates are improved when temperature is increased, thus confirming previously reported results concerning the relationship between temperature and isomerization reaction equilibrium $[13,15,16]$.

Such enzyme features are very attractive from an industrial point of view. In fact, until now the majority of characterized L-AIs are thermoactive and not acid-tolerant. Generating a new acid-tolerant L-AI being highly active at low temperatures would allow the efficient bioconversion of $\mathrm{D}$-galactose into $\mathrm{D}$-tagatose in dairy products during fermentation and/or storage.

\section{Conclusions}

The L-AI from psychrotolerant Shewanella sp. ANA-3 is highly active at a wide $\mathrm{pH}$ range and converts efficiently Dgalactose into D-tagatose even at low temperatures. These biochemical properties are of interest for industrial purposes. Indeed, isomerization of $\mathrm{D}$-galactose at acid $\mathrm{pH}$ prevents the formation of unwanted side-products and high stability at low temperatures is convenient for food industry applications. The T268K mutation did not change enzyme behavior regarding temperature but clearly enhanced the enzyme activity and stability at low $\mathrm{pH}$ values.

Further work will target the overexpression of this particular enzyme in a food-grade system such as lactic

Table 3 Kinetics of D-galactose bioconversion rates using the purified enzyme $(1 \mathrm{mg} / \mathrm{ml})$ at different temperatures

\begin{tabular}{|c|c|c|c|c|c|}
\hline Temperature $\left({ }^{\circ} \mathrm{C}\right)$ & 4 & 10 & 20 & 30 & 35 \\
\hline Time (h) & & Bioconversion rate (\%) & & & \\
\hline 1.0 & $6.0 \pm 0.1$ & $6.0 \pm 0.2$ & $9.0 \pm 0.1$ & $10 \pm 0.5$ & $11 \pm 0.1$ \\
\hline 2.0 & $9.0 \pm 0.2$ & $8.0 \pm 0.5$ & $12 \pm 0.5$ & $14 \pm 0.2$ & $16 \pm 0.3$ \\
\hline 3.0 & $12 \pm 0.1$ & $12 \pm 0.3$ & $17 \pm 0.8$ & $19 \pm 0.7$ & $22 \pm 0.4$ \\
\hline 4.0 & $15 \pm 0.4$ & $18 \pm 0.7$ & $20 \pm 0.4$ & $25 \pm 0.9$ & $28 \pm 0.7$ \\
\hline 5.0 & $16 \pm 0.8$ & $20 \pm 0.6$ & $24 \pm 0.6$ & $29 \pm 0.6$ & $32 \pm 0.6$ \\
\hline 6.0 & $16 \pm 0.2$ & $21 \pm 0.2$ & $25 \pm 0.5$ & $30 \pm 0.4$ & $34 \pm 0.1$ \\
\hline 7.0 & $16 \pm 0.3$ & $21 \pm 0.5$ & $25 \pm 0.2$ & $31 \pm 0.3$ & $34 \pm 0.8$ \\
\hline
\end{tabular}


acid bacteria. Given the attractive properties of the enzyme it would be of high interest to employ it as a model for optimization of the bioconversion of D-galactose into D-tagatose in milk and dairy products such as yoghurts. In order to improve the suitability of this biocatalyst for industrial applications it is important to increase its affinity to D-galactose. For this purpose crystallization followed by the determination of the threedimensional structure of this protein in complex with substrates by X-ray crystallography in combination with protein engineering are underway. Such data will allow improving the efficiency of other food-grade L-AIs.

\section{Methods}

Bacterial strains, plasmids and media

Shewanella sp. ANA-3 strain was routinely grown as reported by Saltikov et al. [28]. Escherichia coli BL21 (DE3) were used in this study as host strains. Culture of different E. coli strains was done in Luria Bertani (LB) medium. These media were supplemented, when necessary, with ampicillin $(100 \mu \mathrm{g} / \mathrm{ml})$ and IPTG (Isopropyl $\beta$-D-thiogalactopyranoside) at $160 \mu \mathrm{g} / \mathrm{ml}$. The pGEMTEasy (Promega) and pET-15b plasmids (Novagen) were used according to the manufacturer's instructions.

\section{DNA manipulation and PCR}

Genomic DNA was prepared as reported by Johnson [29]. Preparation of plasmid DNA, digestion with restriction endonucleases and separation of fragments by agarose gel electrophoresis were performed as described by Sambrook et al. [30]. PCRs were carried out using Gene Amp ${ }^{\circledR}$ PCR System 9700 (Applied Biosystems). The amplification reaction mixtures $(100 \mu \mathrm{l})$ contained High Fidelity Taq amplification buffer, 20 pmol of each primer, 100 ng of DNA template, and 10 units of High-Fidelity Taq DNA polymerase (Invitrogen). The cycling parameters were $94^{\circ} \mathrm{C}$ for $5 \mathrm{~min}$, followed by 40 cycles of $94^{\circ} \mathrm{C}$ for $30 \mathrm{~s}, 55^{\circ} \mathrm{C}$ for $60 \mathrm{~s}$, and $72^{\circ} \mathrm{C}$ for $120 \mathrm{~s}$. The amplified fragment containing the Shewanella sp. ANA-3 araA gene was sequenced using an automated DNA sequencer (Applied Biosystems).

\section{Cloning and over-expression of the araA Shewanella sp. ANA-3 gene}

Aiming the amplification of the Shewanella sp. ANA-3 $\operatorname{ara} A$ gene, we designed two primers based on the complete genome available in the NCBI databank. Oligonucleotide sequences were $\mathrm{F}$-araA ${ }^{5}$ 'GATAAGCACTA TTTGCGTAAGCATG ${ }^{3 \prime}$ and R-araA ${ }^{5}$ ' TTATTGCTGC GCAGAATTATAAACCTCTTGCTAAACCG ${ }^{3}$. Chromosomal DNA isolated from Shewanella sp. ANA-3 strain was used as a template and High-Fidelity Taq DNA polymerase for amplification. The PCR product was purified using QIAquick Gel Extraction Kit $\left(\right.$ QIAGEN $\left.^{\circledR}\right)$ by following the manufacturer's instructions. Subsequently, the resulting fragments were cloned in pGEMT-Easy Vector (Promega) and transformed into E. coli BL21 (Invitrogen) competent cells. Recombinant white clones were selected on LB agar medium added with ampicillin (100 $\mu \mathrm{g} / \mathrm{ml})$, IPTG $(160 \mu \mathrm{g} / \mathrm{ml})$ and X-gal $(100 \mu \mathrm{g} / \mathrm{ml})$. Then, the $\operatorname{araA}$ gene was subcloned in the pET-15b (Novagen) under the control of the T7 promoter with six histidines at the N-terminal end of the protein. The T268K L-AI mutant was generated by using a site-directed mutagenesis Kit purchased from Stratagene (used as recommendation by supplier) and oligonucleotides T268Kd ${ }^{5}$ AACCTCA CTGGCATGAAAGGATTACCCGGACTG ${ }^{3{ }^{\prime}}$ and T268Kr ${ }^{5}$ CAGTCCGGGTAATCCTTTCATGCCAGTGAGGTT ${ }^{3}$.

\section{Amino acid sequence alignment}

The multiple alignment of the L-AI amino-acid sequence was done using the program ClustalW [31] and the figure rendering was done using the ESPript sequence analysis server [32].

\section{Crude cell-lysate preparation and enzyme purification}

The recombinant Escherichia coli strains, overexpressing Shewanella sp. ANA-3 L-AI, were grown in LB medium with ampicillin $(100 \mu \mathrm{g} / \mathrm{ml})$. From this culture a second one was launched under the same conditions at $200 \mathrm{rpm}$ and $37^{\circ} \mathrm{C}$. The culture was supplemented with IPTG $(0.5$ $\mathrm{mM})$ at $\mathrm{OD}_{600 \mathrm{~nm}}$ of 1.0 and subsequently incubated at $37^{\circ}$ $\mathrm{C}$ and $220 \mathrm{rpm}$ for over-night. Cells were harvested by centrifugation $\left(6500 \times g\right.$ for $10 \mathrm{~min}$ at $\left.4^{\circ} \mathrm{C}\right)$ and the pellets were re-suspended in $100 \mathrm{mM}$ MES buffer at pH 5.5 supplemented with one Complete ${ }^{\mathrm{TM}}$ protease inhibitor cocktail tablet $\left(\right.$ Roche $\left.^{\circledR}\right)$. Cell disruption was carried out, twice, using a French Press at 1000 psi. For the purification, crude cell extract from the $E$. coli BL21 (DE3) strain was centrifuged $\left(30000 \times g\right.$, for $30 \mathrm{~min}$ at $\left.4^{\circ} \mathrm{C}\right)$. Proteins precipitated between 60 and $70 \%$ ammonium sulphate saturation, suspended in 100 mM MES buffer $\mathrm{pH} 5.5$, concentrated and desalted in centrifugal micro-concentrators (Amicon, Inc) with a $30 \mathrm{kDa}$ cut-off membrane. Then, an affinity chromatography was done using IMAC column on the ÄKTA Purifier FPLC system (Amersham Pharmacia Biotech) equilibrated with $100 \mathrm{mM}$ MES buffer $\mathrm{pH}$ 5.5. Proteins were eluted at a flow rate of $3 \mathrm{ml} / \mathrm{min}$ using a linear imidazole gradient ranging from 0 to $500 \mathrm{mM}$ in the same MES buffer with imidazole $(500 \mathrm{mM})$. Fractions containing L-AI activity were pooled and the final purification phase was performed using size exclusion chromatography on a Sephacryl S-200 column (GE-Healthcare).

\section{Protein quantification, electrophoresis and molecular mass determination}

Protein concentration was determined using Bradford's method with bovine serum albumin as standard [33]. 
The protein samples were separated in 12\% SDS-PAGE gel according to the Laemmli method, and bands were visualized by Coomassie brilliant blue R-250 (Biorad) staining. The estimated molecular mass of the purified L-AI was determined by size exclusion chromatography.

\section{Enzyme activity assays}

L-AI activity was measured by determining the amount of formed L-ribulose or D-tagatose. Under standard conditions, the reaction mixture contained $100 \mu$ l of enzyme ( $\mathrm{L}-\mathrm{AI}$ ) preparation at a $1 \mathrm{mg} / \mathrm{ml}, 50 \mathrm{mM}$ of $\mathrm{L}$-arabinose (D-galactose) and $100 \mathrm{mM}$ MES buffer ( $\mathrm{pH} 5.5)$ in a final volume of $1 \mathrm{ml}$. The reaction was stopped by heating the mixture at $99^{\circ} \mathrm{C}$ for $2 \mathrm{~min}$. The amount of L-ribulose (or D-tagatose) was colorimetrically determined using the cystein-carbazol-sulphuric-acid method and the absorbance was measured at $560 \mathrm{~nm}$ [34]. D-Tagatose production was also detected with high-performance ionic chromatography (HPLC) using a Polypore CA column $(250 \times 4.6 \mathrm{~mm})$. The products were separated by isocratic elution with water at a flow rate of $0.3 \mathrm{ml} / \mathrm{min}$ and detected with a refractive index detector (SHIMADZU, Refractive Index Detector). Solutions of $5 \mathrm{~g} / \mathrm{l} \mathrm{D}$-galactose and $5 \mathrm{~g} / \mathrm{l} \mathrm{D}$-tagatose were used as standards.

One unit of L-AI activity was defined as the amount of enzyme catalyzing the formation of $1 \mu \mathrm{mol}$ keto-sugar per min under the above-specified conditions.

\section{Temperature, $\mathrm{pH}$ and thermostability profiles}

The effect of temperature on the activity was studied by incubating the purified protein at temperatures from 4 to $55^{\circ} \mathrm{C}$. The enzyme $\mathrm{pH}$ profile was obtained at $\mathrm{pH}$ values between 3.0 and 8.5 (3.0 to 5.0 with sodium acetate buffer, 5.5 to 7.0 with MES buffer and 7.5 to 9.0 with Bicine buffer). Determination of the enzyme stability as a function of temperature and $\mathrm{pH}$ was carried out by measuring the residual activity at periodic intervals.

\section{Effect of metal ions on the enzymatic activity}

Shewanella sp. ANA-3 L-AI was purified as described in the enzyme purification section but without addition of metal ions to the crude extract and dialyzed against 100 mM MES buffer ( $\mathrm{pH}$ 5.5) containing 10 mM EDTA for 48 $\mathrm{h}$ at $4^{\circ} \mathrm{C}$ (buffer renewed twice). Subsequently, we twice dialyzed the EDTA-treated enzyme against $100 \mathrm{mM}$ MES buffer ( $\mathrm{pH}$ 5.5). Thereafter, the enzyme was pre-incubated during $10 \mathrm{~min}$ in solutions containing metal ions $\left(\mathrm{CuSO}_{4}\right.$, $\mathrm{CaSO}_{4}, \mathrm{MnSO}_{4}, \mathrm{FeSO}_{4}, \mathrm{BaSO}_{4}, \mathrm{CoSO}_{4}, \mathrm{FeSO}_{4}, \mathrm{MgSO}_{4}$ ) followed by L-AI activity assays under standard conditions. The optimal metal ion concentrations were monitored by incubating the enzyme samples at various concentrations followed by activity assays.

\section{Flame atomic absorption spectrometry analysis}

For sample preparation, each mineralized sample was employed at a final concentration evaluated to $10 \mathrm{mg} /$ ml. A Perkin-Elmer Analyst 200 atomic absorption (Norwalk, USA), equipped with a deuterium lamp background correction system, was used for metal binding quantification. Hollow cathode lamps (Perkin-Elmer) were used as primary radiation source. Analytical measurements were based on time average absorbance, under conditions recommended by the manufacturer.

\section{Determination of kinetic parameters}

Kinetic parameters were determined on the basis of Lineweaver-Burk plots. Assays were carried out in 100 mM MES buffer (pH 5.5), $0.6 \mathrm{mM} \mathrm{Mn}^{2+}$ and 1 to 800 $\mathrm{mM}$ substrate (L-arabinose or D-galactose). Samples were incubated at $35^{\circ} \mathrm{C}$ and the amount of keto-sugar generated (L-ribulose or $\mathrm{D}$-tagatose) was determined by the cysteine-carbazole-sulfuric acid method.

\section{Bioconversion assays}

Bioconversion of D-galactose into D-tagatose was monitored in a solution containing $100 \mathrm{mM}$ MES buffer ( $\mathrm{pH}$ 5.5), $0.6 \mathrm{mM} \mathrm{Mn}^{2+}$ and $50 \mathrm{mM}$ D-galactose. Kinetic conversion of $D$-galactose was investigated for $7 \mathrm{~h}$ at 4,10 , 20,30 and $35^{\circ} \mathrm{C}$. Samples were taken periodically and the concentration of generated $\mathrm{D}$-tagatose was determined as described earlier and confirmed by HPLC as indicated in the enzyme assay section.

\section{List of abbreviations \\ L-Al: L-arabinose isomerase; MES: 2(-N-morpholino)ethanesulfonic acid; EDTA: Ethylenediaminetetraacetic acid; HPLC: High-performance liquid \\ chromatography; IPTG: Isopropyl $\beta$-D-thiogalactopyranoside; PCR: Polymerase Chain Reaction; RT: Retention Time; SDS-PAGE: Sodium Dodecyl Sulfate \\ Polyacrylamide Gel Electrophoresis.}

\section{Acknowledgements}

We acknowledge Dr. Chad SALTIKOV from California Institute of Technology for generously providing us the Shewanella sp. ANA-3 strain. The authors would like to express their gratitude to Dr Michel JUY and Magali DEJOB in the Laboratory for BioCrystallography and Structural Biology of Therapeutic Targets and to Dr Annie CHABOUD for protein Production and Analysis facility, SFR BioSciences Lyon-Gerland UMS3444/US8 (France).

\section{Author details}

${ }^{1}$ Laboratory for BioCrystallography and Structural Biology of Therapeutic Targets, "Bases Moléculaires et Structurales des Systèmes Infectieux" UMR5086 CNRS/Université de Lyon1, Institut de Biologie et Chimie des Protéines FR3302, 7 Passage du Vercors, F-69367 Lyon cedex 07, France. ${ }^{2}$ Institut National de la Recherche Agronomique, UMR 1319 Micalis, F-78350 Jouy-en-Josas, France.

\section{Authors' contributions}

MR participated in the design of the study, experiments analysis and writing the manuscript. GB participated in the molecular biology experiments. IR participated in the biochemical experiments. SB participates in the construction of mutant and expression of proteins. EM participated in the design of the work. $\mathrm{RH}$ participated in the conception of mutant. AN 
participated in the design of the work and helped in drafting the manuscript. All authors read and approved the final manuscript.

\section{Competing interests}

The authors declare that they have no competing interests.

Received: 5 September 2011 Accepted: 10 November 2011 Published: 10 November 2011

\section{References}

1. Kim P, Yoon SH, Seo MJ, Oh DK, Choi JH: Improvement of tagatose conversion rate by genetic evolution of thermostable galactose isomerase. Biotechnol Appl Biochem 2001, 34(2):99-102.

2. Izumori K, Ueda Y, Yamanaka K: Pentose metabolism in Mycobacterium smegmatis: comparison of L-arabinose isomerases induced by Larabinose and D-galactose. J Bacteriol 1978, 133(1):413-414.

3. Roh HJ, Kim P, Park YC, Choi JH: Bioconversion of D-galactose into Dtagatose by expression of L-arabinose isomerase. Biotechnol Appl Biochem 2000, 31(1):1-4.

4. Levin GV: Tagatose, the new GRAS sweetener and health product. J Med Food 2002, 5(1):23-36.

5. Lu Y, Levin GV, Donner TW: Tagatose, a new antidiabetic and obesity control drug. Diabetes Obes Metab 2008, 10(2):109-134.

6. Saunders JP, Donner TW, Sadler JH, Levin GV, Makris NG: Effects of acute and repeated oral doses of D-tagatose on plasma uric acid in normal and diabetic humans. Regul Toxicol Pharmacol 1999, 29(2):S57-S65.

7. Rhimi M, Messaoud EB, Borgi MA, Khadra KB, Bejar S: Co-expression of Larabinose isomerase and $\mathrm{D}$-glucose isomerase in $E$. coli and development of an efficient process producing simultaneously Dtagatose and D-fructose. Enzyme and Microbial Technology 2007, 40(6):1531-1537.

8. Levin GV, Zehner LR, Saunders JP, Beadle JR: Sugar substitutes: their energy values, bulk characteristics, and potential health benefits. Am J Clin Nutr 1995, 62(5):1161S-1168S

9. Manzoni M, Rollini M, Bergomi S: Biotransformation of D-galactitol to tagatose by acetic acid bacteria. Process biochemistry 2001, 36:971-977.

10. Kim BC, Lee YH, Lee HS, Lee DW, Choe EA, Pyun YR: Cloning, expression and characterization of L-arabinose isomerase from Thermotoga neapolitana: bioconversion of D-galactose to D-tagatose using the enzyme. FEMS Microbiol Lett 2002, 212(1):121-126.

11. Jorgensen F, Hansen OC, Stougaard P: Enzymatic conversion of Dgalactose to D-tagatose: heterologous expression and characterization of a thermostable L-arabinose isomerase from Thermoanaerobacter mathranii. Appl Microbiol Biotechnol 2004, 64(6):816-822.

12. Kim HJ, Oh DK: Purification and characterization of an L-arabinose isomerase from an isolated strain of Geobacillus thermodenitrificans producing D-tagatose. J Biotechnol 2005, 120(2):162-173.

13. Rhimi M, Bejar S: Cloning, purification and biochemical characterization of metallic-ions independent and thermoactive L-arabinose isomerase from the Bacillus stearothermophilus US100 strain. Biochim Biophys Acta 2006, 1760(2):191-199.

14. Prabhu P, Tiwari MK, Jeya M, Gunasekaran P, Kim IW, Lee JK: Cloning and characterization of a novel L-arabinose isomerase from Bacillus licheniformis. Appl Microbiol Biotechnol 2008, 81(2):283-290.

15. Lee SJ, Lee DW, Choe EA, Hong YH, Kim SB, Kim BC, Pyun YR: Characterization of a thermoacidophilic L-arabinose isomerase from Alicyclobacillus acidocaldarius: role of Lys-269 in pH optimum. Appl Environ Microbiol 2005, 71(12):7888-7896.

16. Lee DW, Jang HJ, Choe EA, Kim BC, Lee SJ, Kim SB, Hong YH, Pyun YR: Characterization of a thermostable L-arabinose (d-galactose) isomerase from the hyperthermophilic eubacterium Thermotoga maritima. Appl Environ Microbiol 2004, 70(3):1397-1404

17. Hong YH, Lee DW, Lee SJ, Choe EA, Kim SB, Lee YH, Cheigh Cl, Pyun YR: Production of D-tagatose at high temperatures using immobilized Escherichia coli cells expressing L-arabinose isomerase from Thermotoga neapolitana. Biotechnol Lett 2007, 29(4):569-574.

18. Kim JW, Kim YW, Roh HJ, Kim HY, Cha JH, Park KH, Park CS: Production of tagatose by a recombinant thermostable L-arabinose isomerase from Thermus sp. IM6501. Biotechnol Lett 2003, 25(12):963-967.
19. Rhimi M, Juy M, Aghajari N, Haser R, Bejar S: Probing the essential catalytic residues and substrate affinity in the thermoactive Bacillus stearothermophilus US100 L-arabinose isomerase by site-directed mutagenesis. J Bacteriol 2007, 189(9):3556-3563.

20. Prabhu $P$, Jeya $M$, Lee JK: Probing the molecular determinant for the catalytic efficiency of L-arabinose isomerase from Bacillus licheniformis. Appl Environ Microbiol 2010, 76(5):1653-1660.

21. Chouayekh H, Bejar W, Rhimi M, Jelleli K, Mseddi M, Bejar S: Characterization of an L-arabinose isomerase from the Lactobacillus plantarum NC8 strain showing pronounced stability at acidic $\mathrm{pH}$. FEMS Microbiol Lett 2007, 277(2):260-267.

22. Rhimi M, Aghajari N, Juy M, Chouayekh H, Maguin E, Haser R, Bejar S: Rational design of Bacillus stearothermophilus US100 L-arabinose isomerase: potential applications for D-tagatose production. Biochimie 2009, 91(5):650-653.

23. Manjasetty BA, Chance MR: Crystal structure of Escherichia coli I-arabinose isomerase (ECAl), the putative target of biological tagatose production. $J$ Mol Biol 2006, 360(2):297-309.

24. Rhimi M, Ilhammami R, Bajic G, Boudebbouze S, Maguin E, Haser R, Aghajari $\mathrm{N}$ : The acid tolerant L-arabinose isomerase from the food grade Lactobacillus sakei $23 \mathrm{~K}$ is an attractive D-tagatose producer. Bioresour Technol 2010, 101(23):9171-9177.

25. Li Y, Zhu Y, Liu A, Sun Y: Identification and characterization of a novel Larabinose isomerase from Anoxybacillus flavithermus useful in D-tagatose production. Extremophiles 2011, 15(3):441-450.

26. Lee D, Jang H, Choe E, Kim B, Lee S, Kim S, Hong Y, Pyun Y: Characterization of a thermostable L-arabinose (d-galactose) isomerase from the hyperthermophilic eubacterium Thermotoga maritima. Appl Environ Microbiol 2004, 70(3):1397-1404.

27. Lee DW, Choe EA, Kim SB, Eom SH, Hong YH, Lee SJ, Lee HS, Lee DY, Pyun YR: Distinct metal dependence for catalytic and structural functions in the L-arabinose isomerases from the mesophilic Bacillus halodurans and the thermophilic Geobacillus stearothermophilus. Arch Biochem Biophys 2005, 434(2):333-343

28. Saltikov CW, Cifuentes A, Venkateswaran K, Newman DK: The ars detoxification system is advantageous but not required for $\mathrm{As}(\mathrm{V})$ respiration by the genetically tractable Shewanella species strain ANA-3. Appl Environ Microbiol 2003, 69(5):2800-2809.

29. Johnson J: Genetic characterization. In Manual of methods for general bacteriology. Edited by: Gerhardt P, Murray RGE, Costilow RN, Nester EW, Wood WA, Krieg NR, Phillips GB. American Society for Microbiology, Washington DC; 1981 :

30. Sambrook J, Fritsch EF, T M: Molecular cloning: a laboratory manual. Cold Spring Harbor Laboratory Press, Cold Spring Harbor, New York, USA ; 2 1989.

31. Thompson JD, Higgins DG, Gibson TJ: CLUSTAL W: improving the sensitivity of progressive multiple sequence alignment through sequence weighting, position-specific gap penalties and weight matrix choice. Nucleic Acids Res 1994, 22(22):4673-4680.

32. Gouet P, Robert X, Courcelle E: ESPript/ENDscript: Extracting and rendering sequence and $3 D$ information from atomic structures of proteins. Nucleic Acids Res 2003, 31(13):3320-3323.

33. Bradford MM: A rapid and sensitive method for the quantification of microgram quantities of protein utilizing the principle of protein-dye binding. Anal Biochem 1976, 72(1-2):248-254.

34. Laemmli UK: Cleavage of structural proteins during the assembly of the head of bacteriophage T4. Nature 1970, 227:680-685.

35. Cheng $L, M u$ W, Zhang T, Jiang B: An L-arabinose isomerase from Acidothermus cellulolytics ATCC 43068: cloning, expression, purification, and characterization. Appl Microbiol Biotechnol 2010, 86(6):1089-1097.

36. Kim JH, Prabhu P, Jeya M, Tiwari MK, Moon HJ, Singh RK, Lee JK: Characterization of an L-arabinose isomerase from Bacillus subtilis. Appl Microbiol Biotechnol 2009, 85(6):1839-1847.

37. Patrick JW, Lee N: Purification and properties of an L-arabinose isomerase from Escherichia coli. J Biol Chem 1968, 243(16):4312-4318.

38. Xu Z, Qing Y, Li S, Feng X, Xu H, Ouyang P: A novel L-arabinose isomerase from Lactobacillus fermentum CGMCC2921 for D-tagatose production: Gene cloning, purification and characterization. J Mol Catal B: Enzy 2011, 70(1-2):1-7. 
39. Lifang C, Wanmeng M, Bo J: Thermostable L-arabinose isomerase from Bacillus stearothermophilus IAM 11001 for D-tagatose production: gene cloning, purification and characterisation. J Sci Food Agric 2010, 90(8):1327-1333.

doi:10.1186/1475-2859-10-96

Cite this article as: Rhimi et al: The acid-tolerant L-arabinose isomerase from the mesophilic Shewanella sp. ANA-3 is highly active at low temperatures. Microbial Cell Factories 2011 10:96.

Submit your next manuscript to BioMed Central and take full advantage of:

- Convenient online submission

- Thorough peer review

- No space constraints or color figure charges

- Immediate publication on acceptance

- Inclusion in PubMed, CAS, Scopus and Google Scholar

- Research which is freely available for redistribution

Submit your manuscript at www.biomedcentral.com/submit
() Biomed Central 